\title{
Characterization and antihypertensive activity of ginger extract-eel bone oil SNEDDS (self- nanoemulsifying drug delivery system)
}

Fea Prihapsara ${ }^{1^{*}}$, Imas Ifrian Wijayanti², Agung Budiharjo ${ }^{2,3}$, Artini Pangastuti2,3, Anif Nur Artanti ${ }^{1}$

1 Department of Pharmacy, Faculty of Mathematics and Natural Sciences, Sebelas Maret - University, Central Java, Indonesia

2 Bioscience Graduate Program, Sebelas Maret - University, Central Java, Indonesia 3 Department of Biology, Faculty of Mathematics and Natural Sciences, Sebelas Maret - University, Central Java, Indonesia

*Corresponding author:

Feri Prihapsara

fea.prihapsara@staff.uns.ac.id

Keywords:

Eel bone oil; diastolic; ginger extract; self-nano emulsifying drug delivery system (SNEDDS); systolic https://www.pharmacy.mahidol.ac.th/journal/ (C) Faculty of Pharmacy, Mahidol University (Thailand) 2021

\begin{abstract}
This research aimed to determine the characterization of Self-Nanoemulsifying Drug Delivery System (SNEDDS) of Zingiber officinale extract with eel (Anguilla spp.) bone oil and activity on systolic and diastolic blood pressure of Wistar rats with dexamethasone-induced hypertension. Hypertension was induced by giving rats subcutaneous dexamethasone injections (30 $\mu \mathrm{g} / \mathrm{kg} / \mathrm{day}$ ) for 14 days. In prevention group, rats received oral 200 $\mathrm{mg} / \mathrm{kg}$ BW of crude ginger extract (GE), 200 and $300 \mathrm{mg} / \mathrm{kg}$ BW SNEDDS ginger extract (200 SGE and $300 \mathrm{SGE}$ ), and $40 \mathrm{mg} / \mathrm{kg}$ BW captopril from 4 days before and during treatment period (days 1-18). In curative treatment group, SNEDDS ginger extract was administered orally from days $8-14$. The results, using a UV spectrophotometer showed the transmittance of SNEDDS was 92.16\%; the optimal emulsification time was 10.01 seconds in artificial gastric fluid (AGF), 10.15 seconds in distilled water, and 9.44 seconds in double-distilled water, with a measured particle size of $13.10 \mathrm{~nm}$, polydisperse index 0.134 and zeta potential of -14.04 $\mathrm{mV}$. The antihypertensive activity analyzed by two-way ANOVA $(p<0.05)$ showed that 200 SGE and 300 SGE have effectiveness for preventing symptoms of hypertension. In curative group showed significant different systolic blood pressure between SNEDDS ginger extract and crude ginger extract. This indicated that the tested SNEDDS ginger extract was effective for treating symptoms of hypertension.
\end{abstract}

\section{INTRODUCTION}

Eel (Anguilla spp.) is a food fish that is very popular in many countries, especially Japan, China, Germany, and France, because in addition to a unique taste, it is also very rich in vitamins A, B1, B2, B6, C, and D; albumin; DHA (docosahexaenoic acid); and EPA (eicosapentaenoic acid), better known as omega-3, as well as several other minerals ${ }^{1}$. However, in Indonesia, eel is rarely consumed because of the lack of information on these fish in the community, such that this fish remains unfamiliar to the community.

Fish oil is known as a good source of polyunsaturated fatty acids (PUFA) and is widely used for pharmaceutical purposes and in food supplements. Eel has important economic value for both local both local and foreign markets. The market demand for eel, mainly from Japan and Korea, is very high, being up to 500,000 tons per year; the main suppliers of eel are China and Taiwan. Eel, known 
as unagi in Japan, is very expensive because it has a high protein content of $16.4 \%$ and 4700 IU vitamin $\mathrm{A}^{2}$.

Ginger (Zingiber officinale) is a potentially inexpensive and effective natural agent for reducing the risk factors for hypertension and hyperlipidemia in ischemic heart disease (IHD), reducing the potential for various cardiovascular diseases with minimal adverse effects ${ }^{3}$. Some studies have shown that the mechanism of ginger in reducing hypertension risk factors include inhibiting hydroxymethylglutaryl coenzyme A (HMG$\mathrm{CoA}$ ) reductase, an enzyme that plays a role in cholesterol biosynthesis, and supports excretion and disrupts cholesterol absorption, which in turn increases the activity of 7alpha-hydroxylase, an enzyme that blocks the conversion of cholesterol catabolic into bile salt in the liver ${ }^{4}$. Ginger extract contains many of phenolic compounds that classified in the Class II Biopharmaceutics Classification System (BCS) which have low solubility but high permeability and less stable when exposed to light. These problems could be overcome by formulations in the form of nanoemulsions to improve its solubility, oral bioavailability, and stability of plant extracts ${ }^{5}$.

The protective cardiovascular effects of fish oil and PUFA reduce blood pressure and prevent the development of hypertension ${ }^{6}$. The cardiovascular protective effect of fish oil is due to the presence of two fatty acids contained in fish oil: EPA and DHA. Dietary supplements that contain both of these fatty acids have protective cardiovascular effects and reduce blood pressure. DHA is more effective in reducing blood pressure and risk factors for cardiovascular disease $\mathrm{e}^{7-8}$. Fish oil is a good source of fatty acids, especially DHA (docohexanoic acid) and EPA (eicosapentanoic acid) ${ }^{9}$. These fatty acids had long chain unsaturated fatty acids which are part of polyunsaturated fatty acids (PUFA). These medium to long chain fatty acids could increase the stability of drug formulations and transport through lymphatic systems to reduce the metabolism pathway and prevent oxidation degradation ${ }^{10}$.

Technologies for improving solubility include surfactants, micronization, salt formation, $\mathrm{pH}$ change, nano-size delivery, solid dispersions, and permeation enhancers. A selfnano emulsifying drug delivery system (SNEDDS) has the advantage of being able to overcome complex problems and improved stability, especially extracts of low-solubility natural ingredients ${ }^{11}$. A SNEDDS is different from microemulsion, where a SNEDDS is more transparent, fully dispersed in water, and is a system with ultra-low interfacial tension so that it is more stable. SNEDDS comprised as isotropic mixtures, such as: oil, surfactant, and co-surfactant. The use of surfactant alone is not enough to reduce the face tension so. Cosurfactant are needed to increase the fluidity of the interface and then will increase system entropy $^{12}$. According to Bhattacharjee ${ }^{13}$, with good stabilization, nanoemulsion can be stored for a longer time than microemulsion.

The objectives of this present study were to find the optimum formula composition of the ginger extract-eel bone oil SNEDDS, and its antihypertensive activity in dexamethasoneinduced rats. Here, the effectiveness of the active ingredient in ginger with the PUFA content in eel bone oil, and the presence of surfactants and cosurfactants have protective cardiovascular effects; moreover, the smaller particle size allows more optimal absorption of the present system in the digestive tract.

\section{MATERIALS AND METHODS}

\subsection{Ginger extraction}

The ginger powder was extracted using the maceration method by immersing $900 \mathrm{~g}$ powder with ethanol p.a ( $\geq 99.9 \%$ ) (Merck, Germany), with a powder:solvent ratio of 1:5. The powder was soaked in ethanol for 3 days, with 30-minutes stirring every 24 hours. The mixture was filtered using a glass funnel with a flannel cloth to separate the macerate. The obtained filtrate was re-macerated using ethanol solvent in the same way; ethanol evaporation was then performed at $76^{\circ} \mathrm{C}$ in a rotary evaporator (RVO 400 SD, Boeco Germany) at $100 \mathrm{rpm}$ until the volume of macerate was reduced by about one-third. The evaporated macerate was heated over a $50^{\circ} \mathrm{C}$ water bath (Grant, UK) until a thick extract was obtained. The quality control of ginger extract was obtained, i.e.: rendement $(8.85 \%(\mathrm{w} / \mathrm{w}))$, moisture content $(8.55 \%)$, and total phenolic content $(48.52 \pm 0.37 \mu \mathrm{g} / \mathrm{ml})$.

\subsection{Preparation of SNEDDS}

The SNEDDS was prepared by adding $1000 \mathrm{mg}$ ginger extract per $5 \mathrm{~g}$ SNEDDS system in a $10 \mathrm{~mL}$ tube and mixed with eel oil, Tween 
80 (PT.Brataco, Indonesia), and polyethylene glycol (PEG) 400 (PT.Brataco, Indonesia) according to the predetermined composition. The mixture was homogenized by vortexing for 2 minutes then sonicated in frequency $40 \mathrm{kHz}$ with temperature at $50^{\circ} \mathrm{C}$ for 15 minutes with once cycle number and put in a $45^{\circ} \mathrm{C}$ water bath for 10 minutes. Then, it was stirred at $100 \mathrm{rpm}$ for 30 minutes. The mixing results were left to stand for 24 hours at room temperature.

\subsection{Transmittance observations}

The emulsion observation include particle size and distribution was performed using UV/Vis spectrophotometry (Lambda 25, Perkin Elmer, USA) at wavelength $650 \mathrm{~nm}$ and particle size analyzer (PSA). The zeta potential slso were measured by PSA.

\subsection{Emulsification time}

Emulsification time was calculated for the ginger extract nanoemulsion in AGF (Artificial Gastric Fluid). The composition of AGF was $1000 \mathrm{mg}$ of $\mathrm{NaCl}, 3.5 \mathrm{~mL}$ of $\mathrm{HCl} 37 \%$, and $\sim 1 \mathrm{~L}$ of distilled water and the $\mathrm{pH}$ of AGF was adjusted at 1.2. The medium used in this test was $\mathrm{AGF}$ at $37^{\circ} \mathrm{C}$ to mimic the condition of the stomach (gastrointestinal tract). The nanoemulsion was formed by dissolving the 1
$\mathrm{mL}$ of SNEDDS ginger extract thoroughly in the medium. The composition of SNEDDS ginger extract was $1000 \mathrm{mg}$ of ginger extract, 0.55 gram of eel oil, 3.89 gram of Tween 80 , and 0.56 gram PEG 400.

About $250 \mathrm{~mL}$ media was conditioned with a magnetic stirrer at $37^{\circ} \mathrm{C}$ with a speed of $100 \mathrm{rpm}$. About $1.0 \mathrm{~mL}$ of SNEDDS was dropped into the media and observed the time needed for SNEDDS to be completely dispersed and an emulsion was formed. The emulsification time was calculated from the SNEDDS start being dripped until formed an completely emulsion on the media.

\subsection{Characterization of nanoparticle}

About $100 \mu \mathrm{L}$ of SNEDDS was added into distilled water $(\sim 5 \mathrm{~mL})$ and mixed. The mixture was then vortexed for 30 seconds. After this, the mixture was analyzed using Particle Size Analyzer (PSA) with Dynamic Light Scattering (DLS) method was applied to determine the particle size and zeta potential.

\subsection{In vivo testing}

The in vivo test was based on hypertension and antioxidant activity test $\operatorname{method}^{7}$. The determination of hypertension in rats based on criterias, i.e.: (1) comparing systolic

Figure 1. Classification of animal test treatment

\begin{tabular}{|c|c|c|c|c|c|c|c|c|c|c|c|c|c|c|c|c|c|c|}
\hline \multirow{2}{*}{ Groups Test } & \multicolumn{18}{|c|}{ Days } \\
\hline & 1 & 2 & 3 & 4 & 5 & 6 & 7 & 8 & 9 & 10 & 11 & 12 & 13 & 14 & 15 & 16 & 17 & 18 \\
\hline Control Group & \multicolumn{18}{|c|}{ Saline $1 \mathrm{~mL} / \mathrm{kg} \mathrm{BW}$} \\
\hline Group 2 & \multicolumn{18}{|c|}{ Dexamethasone (Dex) $30 \mu \mathrm{g} / \mathrm{kg} \mathrm{BW}$} \\
\hline Group 3 & \multicolumn{4}{|c|}{$\begin{array}{c}\text { Captopril } 30 \mathrm{mg} / \mathrm{kg} \\
\text { BW }\end{array}$} & \multicolumn{14}{|c|}{ Dexamethasone (Dex) $30 \mu \mathrm{g} / \mathrm{kg} \mathrm{BW}+$ Captopril $30 \mathrm{mg} / \mathrm{kg} \mathrm{BW}$} \\
\hline Group 4 & \multicolumn{4}{|c|}{$\begin{array}{l}\text { Ginger extract ( } 200 \\
\mathrm{mg} / \mathrm{kg} \mathrm{BW})\end{array}$} & \multicolumn{14}{|c|}{ Dexamethasone (Dex) $30 \mu \mathrm{g} / \mathrm{kg} \mathrm{BW}+$ Ginger extract $(200 \mathrm{mg} / \mathrm{kg} \mathrm{BW})$} \\
\hline Group 5 & \multicolumn{4}{|c|}{$\begin{array}{l}\text { SNEDDS Ginger } \\
\text { Extract }(200 \mathrm{mg} / \mathrm{kg} \\
\text { BW) }\end{array}$} & \multicolumn{14}{|c|}{$\begin{array}{l}\text { Dexamethasone (Dex) } 30 \mu \mathrm{g} / \mathrm{kg} \mathrm{BW}+\text { SNEDDS Ginger Extract }(200 \mathrm{mg} / \mathrm{kg} \\
\text { BW) }\end{array}$} \\
\hline Group 6 & \multicolumn{4}{|c|}{$\begin{array}{l}\text { SNEDDS Ginger } \\
\text { Extract }(300 \mathrm{mg} / \mathrm{kg} \\
\text { BW })\end{array}$} & \multicolumn{14}{|c|}{$\begin{array}{l}\text { Dexamethasone (Dex) } 30 \mu \mathrm{g} / \mathrm{kg} \mathrm{BW}+\text { SNEDDS Ginger Extract }(300 \mathrm{mg} / \mathrm{kg} \\
\text { BW) }\end{array}$} \\
\hline Group 7 & \multicolumn{7}{|c|}{ Dexamethasone (Dex) $30 \mu \mathrm{g} / \mathrm{kg} \mathrm{BW}$} & \multicolumn{7}{|c|}{$\begin{array}{l}\text { Dexamethasone (Dex) } 30 \mu \mathrm{g} / \mathrm{kg} \mathrm{BW} \\
+ \text { Captopril } 30 \mathrm{mg} / \mathrm{kg} \mathrm{BW}\end{array}$} & \multirow{4}{*}{\multicolumn{4}{|c|}{$\begin{array}{l}\text { saline } 1 \mathrm{ml} / \mathrm{kg} \mathrm{BW} \\
\text { (same as control) }\end{array}$}} \\
\hline Group 8 & \multicolumn{7}{|c|}{ Dexamethasone (Dex) $30 \mu \mathrm{g} / \mathrm{kg} \mathrm{BW}$} & \multicolumn{7}{|c|}{$\begin{array}{l}\text { Dexamethasone (Dex) } 30 \mu \mathrm{g} / \mathrm{kg} \mathrm{BW}+ \\
\text { Ginger extract }(200 \mathrm{mg} / \mathrm{kg} \mathrm{BW})\end{array}$} & & & & \\
\hline Group 9 & \multicolumn{7}{|c|}{ Dexamethasone (Dex) $30 \mu \mathrm{g} / \mathrm{kg} \mathrm{BW}$} & \multicolumn{7}{|c|}{$\begin{array}{l}\text { Dexamethasone (Dex) } 30 \mu \mathrm{g} / \mathrm{kg} \mathrm{BW}+ \\
\text { SNEDDS Ginger Extract }(200 \mathrm{mg} / \mathrm{kg} \\
\text { BW) }\end{array}$} & & & & \\
\hline Group 10 & \multicolumn{7}{|c|}{ Dexamethasone (Dex) $30 \mu \mathrm{g} / \mathrm{kg} \mathrm{BW}$} & \multicolumn{7}{|c|}{$\begin{array}{l}\text { Dexamethasone (Dex) } 30 \mu \mathrm{g} / \mathrm{kg} \mathrm{BW}+ \\
\text { SNEDDS Ginger Extract }(300 \mathrm{mg} / \mathrm{kg} \\
\text { BW) }\end{array}$} & & & & \\
\hline
\end{tabular}

Figure 1. Classification of animal test treatment. 
blood pressure between all groups of rats induced by dexamethasone and groups of rats that were not induced by dexamethasone (normal group), $\mathrm{p}$-value $<0.05$ and (2) systolic blood pressure of all dexamethasone-induced rat groups has reached $\geq 140 \mathrm{mmHg}$. The in vivo test received ethical clearance approval (No. 1.180/HREC/III/2018). The study used male rats (Rattus norvegicus) around 2-3 months old, healthy, and with $\sim 200 \mathrm{~g}$ body weight (BW). The rats were adapted to environmental conditions and fed ad libitum for a week. Hypertension was induced by administering a subcutaneous injection of dexamethasone (30 $\mu \mathrm{g} / \mathrm{kg} / \mathrm{day}$ ) for 14 days. Animals in the saline control group received saline injections $(1 \mathrm{mg} / \mathrm{kg}$ $\mathrm{BW}$ ); the negative control group received dexamethasone injections only. In the preventive treatment group, the animals received oral treatment of GE, 200 SGE, 300 SGE and CAP via intragastric tubes for 4 days before the administration of dexamethasone and during the treatment period (days 1-18). In this study using doses of 200 and $300 \mathrm{mg} / \mathrm{kg}$ BW of SGE because it has better biovability than previous study by Sangal et al. ${ }^{14}(500 \mathrm{mg} / \mathrm{kg} \mathrm{BW}$ via oral treatment). In the curative treatment group, they was administered on days 8-14 (Figure 1). In each group comprised as 10 rats.

\section{RESULTS}

\subsection{The characteristics of SNEDDS of ginger extract with eel oil as a carrier}

The SNEDDS of ginger extract with eel bone oil as a carrier had transmittance values of 92.16\%; emulsification time of 10.01 seconds in AGF, 10.15 seconds in distilled water, and 9.44 seconds in double-distilled water; transmittance particle size showed that the SNEDDS size were $13.10 \mathrm{~nm}$, polydisperse index 0.134 and the zeta potential was $-14.40 \mathrm{mV}$. The loading dose showed $1000 \mathrm{mg} / 5$ grams SNEDDS (Table 1). The transmittance value of $92.16 \%$. shows that the SNEDDS transmittance is close to the distilled water transmittance value of $100 \%$. A greater transmittance value indicates that the particle size is closer to a nanometer.

Table 1. The SNEDDS of ginger extract characters with eel oil as carrier.

\begin{tabular}{ll}
\hline \multicolumn{1}{c}{ Parameter } & Values \\
\hline Particle size & $13.10 \mathrm{~nm}$ \\
Polydisperse index & 0.134 \\
Emulsification Time & \\
AGF & $10.01 \mathrm{~s}$ \\
Distilled water & $10.15 \mathrm{~s}$ \\
Double-distilled water & $9.44 \mathrm{~s}$ \\
Transmittance value & $92.16 \%$ \\
Zeta potensial & $-14.04 \mathrm{mV}$ \\
Loading dose & $1000 \mathrm{mg} / 5$ grams SNEDDS \\
\hline
\end{tabular}

The measurement of emulsification time aimed to determine the time the system requires to be fully dissolved in several liquids, such as distilled water, double-distilled water, and digestive tract liquids, in this case, $\mathrm{AGF}$ at $37^{\circ} \mathrm{C}$. Quicker system emulsification indicates faster absorption. The SNEDDS system emulsification time was $<1$ minute, 10.01 seconds in AGF, 10.15 seconds in distilled water, and 9.44 seconds in doubledistilled water.

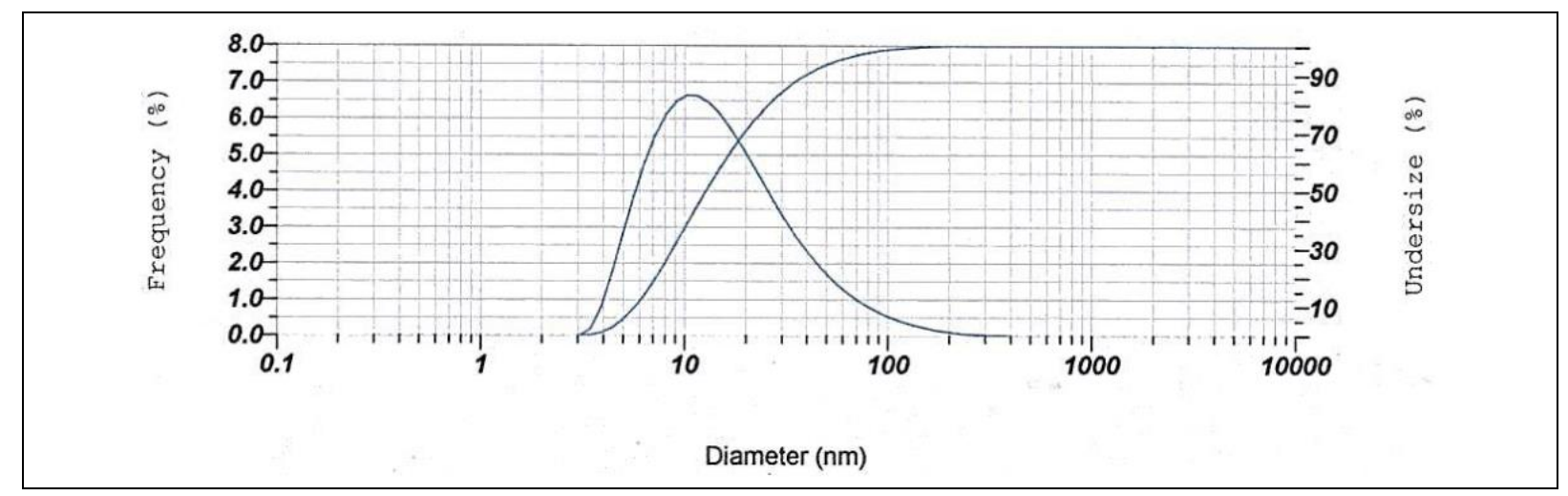

Figure 2. The particle size of the SNEDDS. 
Particle size and the nanoparticle material play an important role in the in vivo pathway of the particle (Figure 2). Zeta potential is a measurement of the repulsion or attraction between particles. This measurement will affect the dispersion mechanism and is the key to electrostatic dispersion control. The potential zeta size of SNEDDS showed $-14.40 \mathrm{mV}$ (Figure 3).

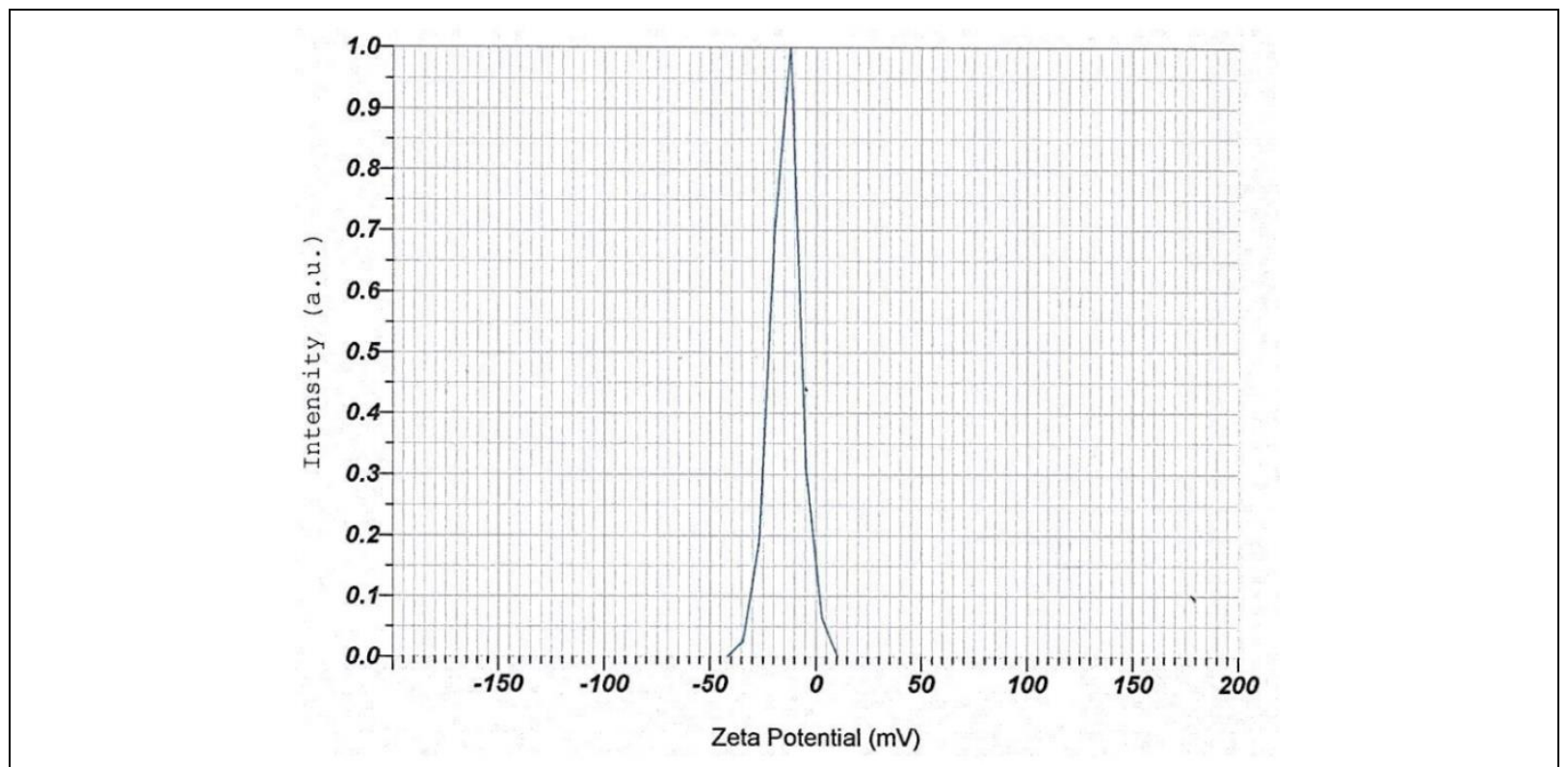

Figure 3. Zeta potential size of the SNEDDS.

\subsection{SNEDDS activity on systolic and diastolic blood pressure}

The first period of systolic and diastolic blood pressure measurements was performed on day 4 for groups 1, 2, 3, 4, 5, 6 and on days 7 in groups 7, 8, 9, and 10. Group 1 was the normal control; group 2 was the negative control, which the rats received subcutaneous injection of dexamethasone for inducing hypertension; groups 3-6 were the preventive treatment groups; groups 7-10 were the curative treatment groups.

The tension measurement above shows that in the preventive groups, systolic (Figure 4) and diastolic (Figure 5) blood pressure were not significantly different from that of the normal group, but were

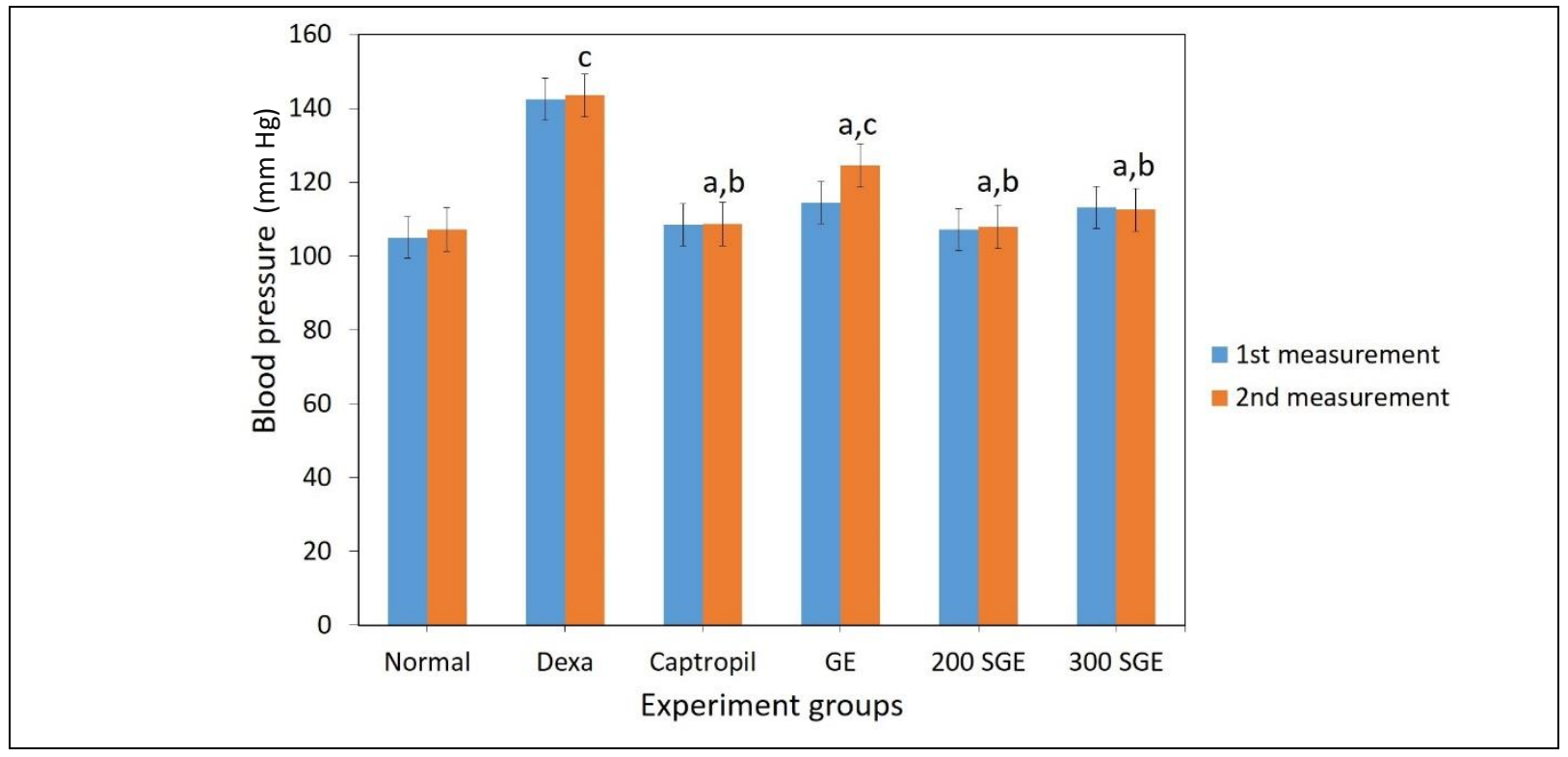

Figure 4. SNEDDS activity on Wistar rat systolic blood pressure in the preventive group.

Values are means \pm SEM. ap $<0.05$ versus DEXA groups, bp $<0.05$ versus GE group, and $\mathrm{cp}<0.05$ versus normal group. 


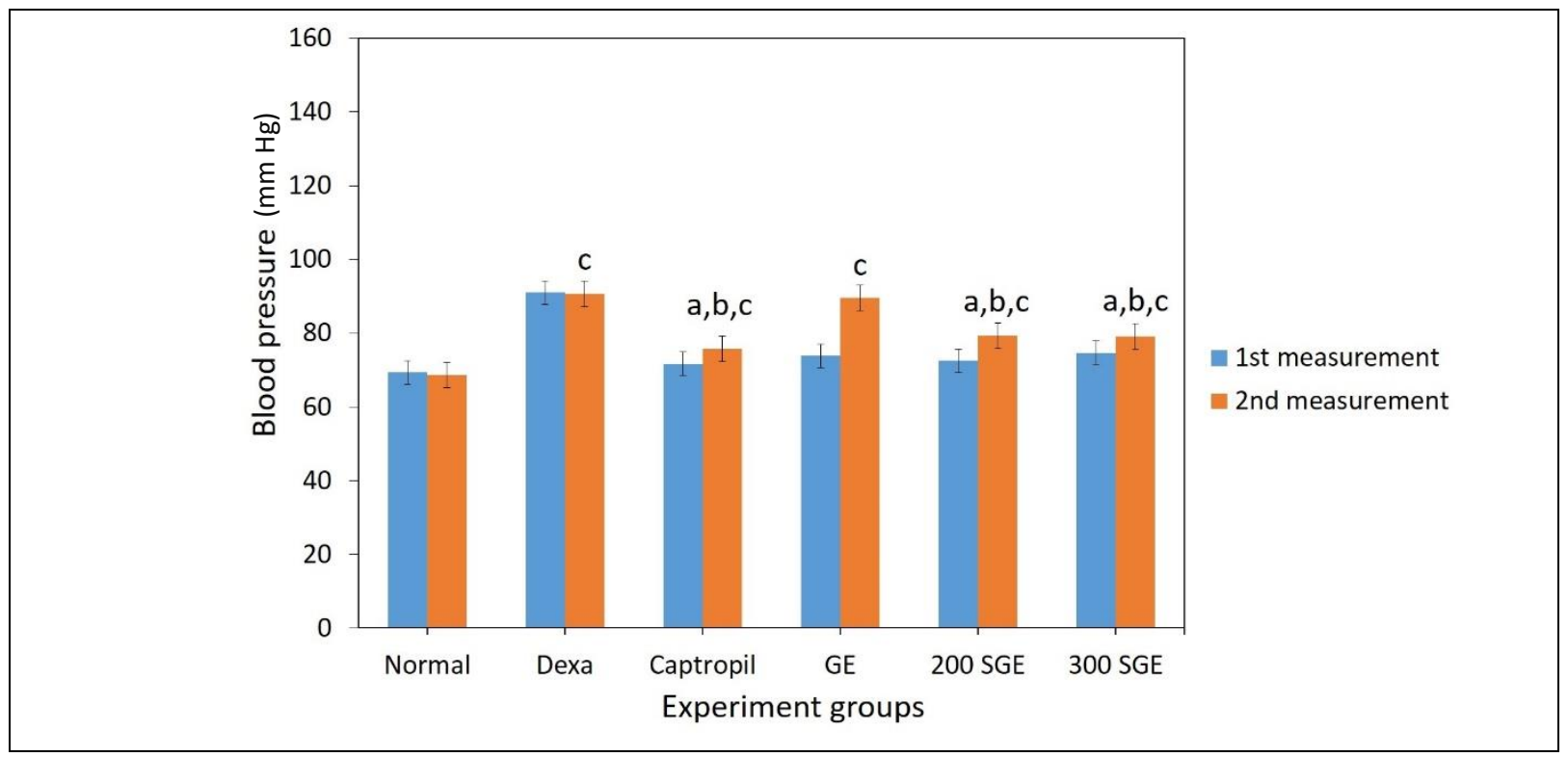

Figure 5. SNEDDS activity on Wistar rat diastolic blood pressure in the preventive group.

Values are means \pm SEM. ap $<0.05$ versus DEXA groups, $b p<0.05$ versus GE group, and $\mathrm{cp}<0.05$ versus normal group.

significantly different from that of the DEXA group. DEXA group, negative control (group 2), received dexamethasone injection for induction of hypertension.

Several antioxidant agents prevent the development of dexamethasone-induced hypertensiono. The second blood pressure measurement was carried out on day 18 in groups $1-6$, and on day 7 and 14 in group 7-10. The systolic (Figure 6) and diastolic (Figure 7) blood pressure measurements showed significant differences between the DEXA group and the preventive and curative groups, whereas the blood pressure of the treatment group did not differ significantly from the normal control group. Analysis of the first and second measurements showed that the blood pressure in the preventive group was not significantly different ( $p<0.05$ ), indicating that the 200 SGE and 300 SGE were effective for preventing hypertension, as was CAP (positive control group). Captopril is a hypertension drug that acts as an angiotensin-converting enzyme (ACE) inhibitor. Compared to the GE group, the $200 \mathrm{SGE}$ and 300 SGE group had a significance different systolic and diastolic blood pressure $(\mathrm{p}<0.05)$.

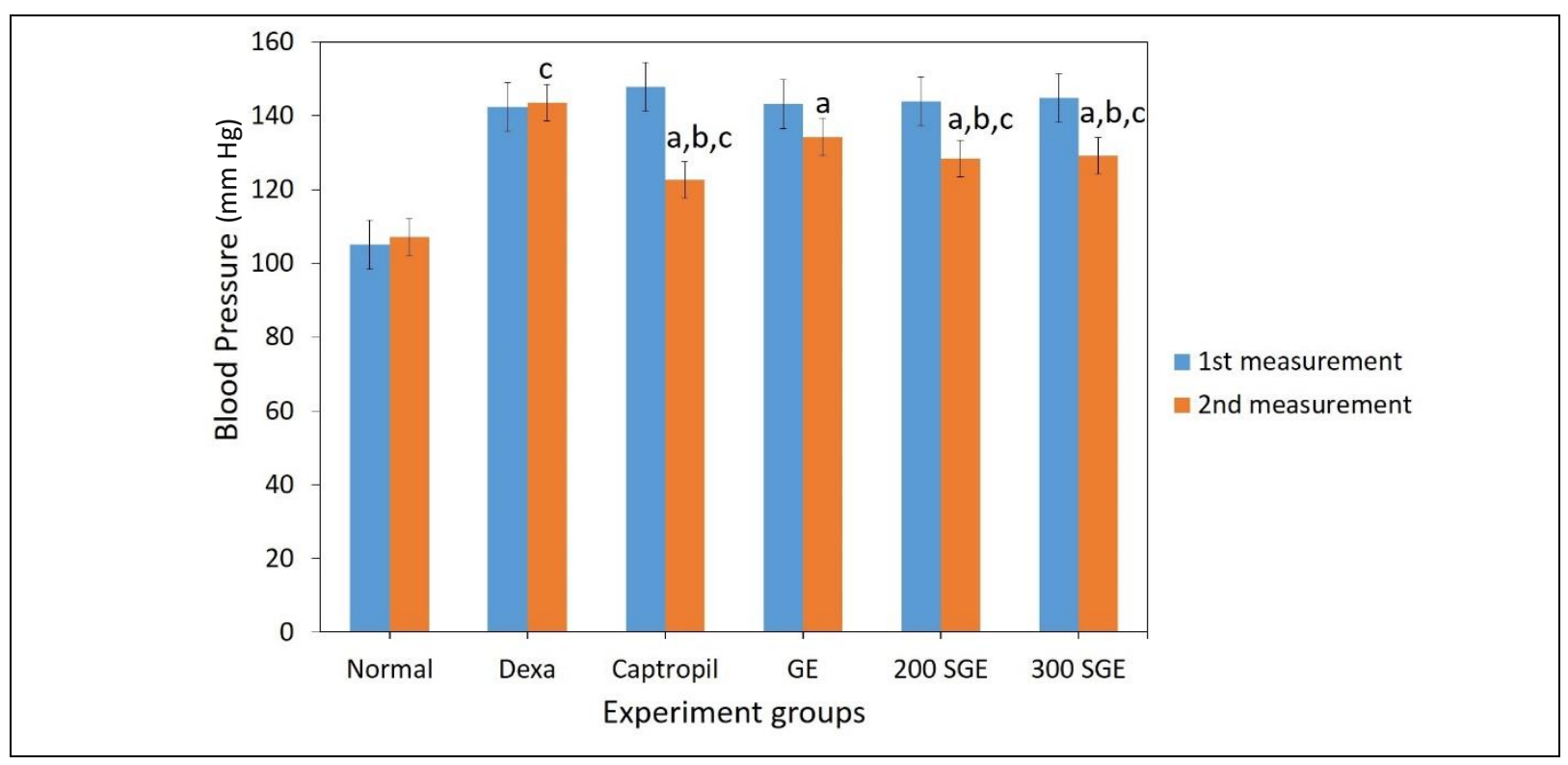

Figure 6. SNEDDS activity on Wistar rat systolic blood pressure in the curative group.

Values are means \pm SEM. ap $<0.05$ versus DEXA groups, $b p<0.05$ versus GE groups, and $\mathrm{cp}<0.05$ versus normal group. 
This shows that SNEDDS was more effective than crude extract.

In the curative treatment, it showed that SNEDDS are effective for treating hypertension, where 200 SGE and 300 SGE had a significance value $(p<0.05)$ as compared to the GE group, indicating that SNEDDS is more effective as a healing agent for hypertension compared to the crude extract.

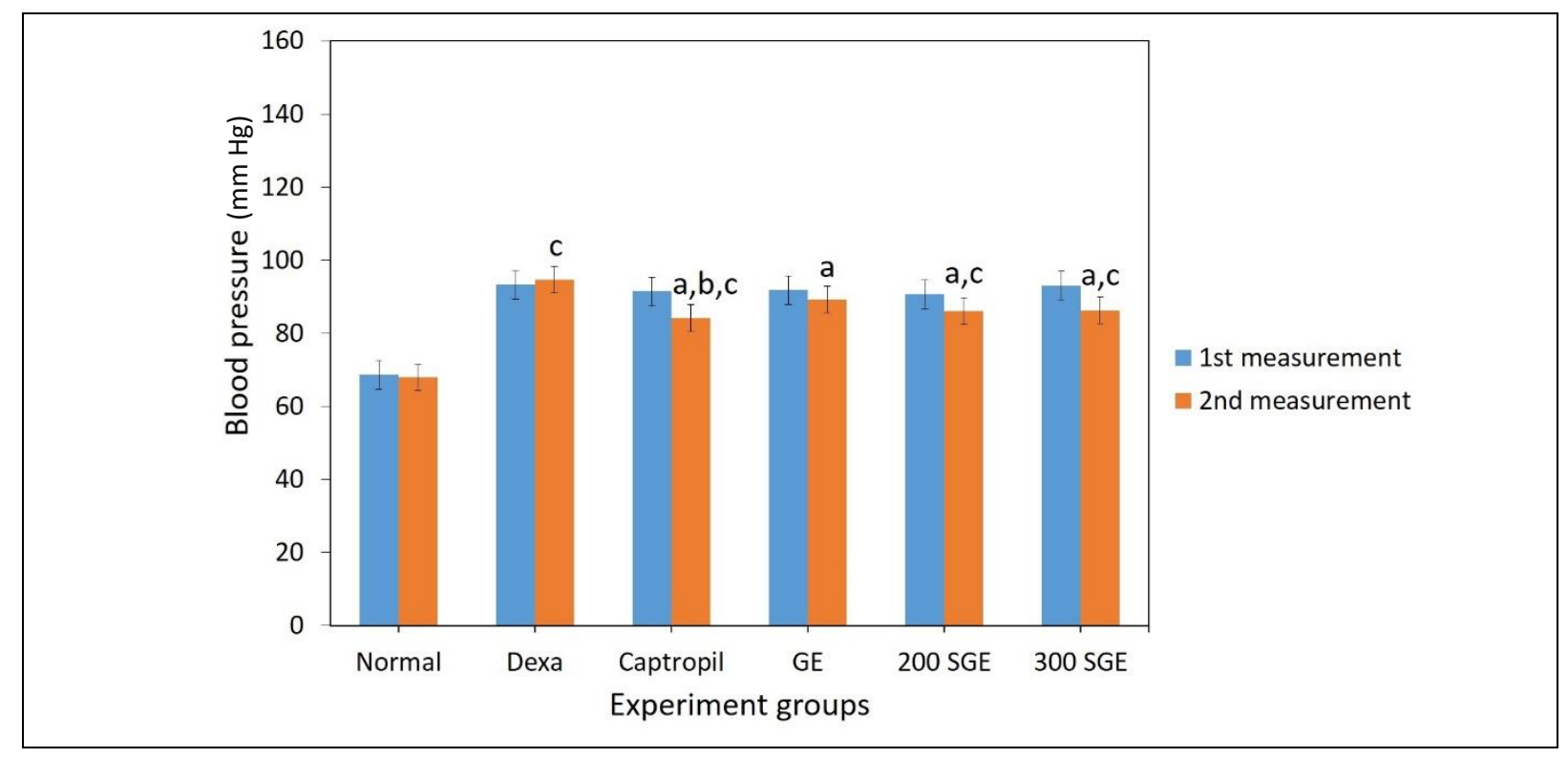

Figure 7. SNEDDS activity on Wistar rat diastolic blood pressure in the curative group.

Values are means \pm SEM. ap $<0.05$ versus DEXA groups, $b p<0.05$ versus GE groups, and $\mathrm{cp}<0.05$ versus normal group.

\section{DISCUSSION}

The administration of an oral drug delivery system can experience several problems. The amount of surface area for absorption in the intestine and the presence of $\mathrm{M}$ cells in some parts of the intestine can be an obstacle to the optimal absorption of active molecules, so a large dose is needed for a small amount of the active substance absorbed. Degradation in the gastrointestinal tract caused by the acidic environment in the stomach and the presence of proteolytic enzymes in the intestine as a physiological defense due to tight junctions can also be a problem ${ }^{15}$. The physicochemical characteristic of the drug that is not under oral drug administration conditions, such as the low solubility in solution/drug stability, can result in low bioavailability. There is extensive research on nanoparticles for overcoming the myriad problems related to the delivery of small molecules and proteins/peptides/active oral agents ${ }^{16}$.

The nanometer particle size can support controlled drug release and greater surface contact in the intestine for attaining optimal absorption ${ }^{17-}$ 18. Nanoparticles can be produced from various materials to adjust the physicochemical characteristics as well as the drug surface selection, which in this case was eel bone oil, to improve the oral bioavailability of the drug ${ }^{19}$. Several studies have revealed that particle size takes precedence over nanoparticle material ${ }^{20}$. Opsonization and the introduction of substances by macrophages are closely related to the size and functional character of the particle surface ${ }^{21}$. Several mechanisms relating to the entry pathway of nanoparticles into cells have been found, including the paracellular pathway (particle size $<50$ $\mathrm{nm}$ ), particle fusion between epithelial cells, insertion by endocytosis (particle size $<500 \mathrm{~nm}$ ), and the endocytosis or lymphatic pathways (particle size $5000 \mathrm{~nm}$ ), where particles are absorbed by $\mathrm{M}$ cells (microfold cells) in Peyer's patches ${ }^{21}$.

In some cases of oral administration, the polymer nanoparticles of $<500 \mathrm{~nm}$ can cross M cells in the intestinal Peyer's patches and can be absorbed easily by the lymphatic system to enter the hepatic presystemic metabolism and increase the bioavailability of the drug. Particles smaller than $200 \mathrm{~nm}$ exhibit reduced looseness, so their circulation time is increased compared to large particles. This phenomenon is because small particles with a small bend radius can prevent opsonin binding more efficiently. Opsonin is an antibody that works by stimulating leukocytes to attack antigens so that nanoparticles of $<200 \mathrm{~nm}$ increase in the blood circulation and exhibit a better targeting effect, especially in the brain ${ }^{21}$. 
Several factors influence a good drug delivery system, including particle size, biocompatibility, specific target affinity, stability in the blood, and controlled release of drug particles, which should be considered in nanoparticle synthesis. Nanoparticle size plays an important role in terms of adhesion and interaction with the biological cells in which the particles will be internalized by receptormediated endocytosis or phagocytosis ${ }^{22}$.

The potential zeta size of SNEDDS indicated that this particle is still not stable (Figure 3) Particle stability is determined in the potential zeta range to be more positive when +30 or more negative when -30 . Here, the zeta potential ranged between -30 and +30 , indicating that the particle is still unstable ${ }^{22}$. The measurement of zeta potential is an important parameter that has been widely applied in several fields, including brewing, ceramics, pharmacy, medicine, mineral processing, and water treatment ${ }^{23}$. The SNEDDS with negative zeta potential contains cation nanoparticles (Figure 3) Some studies suggest that cation nanoparticles in biodegradable polymers such as PLA (polylactide) can be used as a carrier system in DNA and small interfering RNA (siRNA) delivery. Cation nanoparticles combine the advantages of nanoparticles as a drug molecule carrier and the ability of its complexity with nucleic acids as a gene carrier. Cation nanoparticles are a safe, easy, and efficient means of delivering therapeutic molecular compounds $\mathrm{s}^{23}$.

In the present SNEDDS, the ginger extract and its carrier of eel bone oil could reach nanometer size, allowing greater absorption in the digestive tract compared with ginger extract non-SNEDDS ${ }^{24-}$ ${ }^{26}$. In some plants, the phenol compound content indicates the enzyme inhibitor activity. The antioxidant compounds (phenols) found in ginger can also decrease ACE activity. ACE converts angiotensin I to angiotensin II, which is a strong vasoconstrictor that has been identified as a major factor causing hypertension. ACE inhibitors have been developed to prevent the production of angiotensin II in cardiovascular disease ${ }^{27}$.

Dexamethasone is a potential synthetic glucocorticoid that has anti-inflammatory and immunosuppressant abilities and plays a role in various inflammatory activities and autoimmune diseases. Hypertension is a chronic manifestation of dexamethasone application ${ }^{28}$. The increased blood pressure due to the induction of hypertension does not depend on sodium $(\mathrm{Na})$ levels ${ }^{28}$. Therefore, there was no need to add $1 \%$
$\mathrm{NaCl}$ to the animals' drinking water during treatment. One mechanism of increasing blood pressure due to the dexamethasone-induced hypertension is increased blood pressure reactivity through changes in Na/K pump activity ${ }^{29}$.

The continuous use of glucocorticoids such as dexamethasone can cause hypertension by increasing the activity of renin-angiotensin, endothelin, and the sympathetic system, and by altering hemodynamics ${ }^{30}$. Glucocorticoidsinduced hypertension also causes increased oxidative stress and excessive ROS (reactive oxygen species) production. In DEX-HT, increased ROS production in blood vessels occurs through the NADPH oxidase pathway ${ }^{29}$.

\section{CONCLUSIONS}

The cardiovascular-protective SNEDDS of ginger extract with eel bone oil as a carrier has a particle size of $13.10 \mathrm{~nm}$, polydisperse index 0.134 , zeta potential of $-14.40 \mathrm{mV}$, transmittance value of $92.16 \%$, and emulsification time in AGF of 10.01 seconds, in distilled water of 10.15 seconds, and in double-distilled water of 9.44 seconds, conferring it the characteristic of being easily absorbed in the digestive tract.This has been proven via its activity as a preventive and curative agent of hypertension, which shows that this SNEDDS is more effective than crude extract as an antihypertensive agent.

\section{ACKNOWLEDGMENTS}

This work was supported by Grant from Ministry of Research, Technology and Higher Education, Republic of Indonesia.

\section{Conflict of interest}

The authors declare that they have no conflict of interest.

\section{Funding}

None to declare.

Ethics approval

None to declare.

Article info:

Received November 5, 2019

Received in revised form January 23, 2020

Accepted March 30, 2020

\section{REFERENCES}

1. Rovara, O. Transfer of Seed Maintenance Technology for Adapted Eel Fish in the Segara Anakan 
Region [final report]. Jakarta: Agency for the Assessment and Application of Technology; 2010.

2. Haryono. Sidat, Belut Bertelinga: Potensi Dan Aspek Budidayanya. Fauna Indonesia. 2008;8(1):22-6.

3. Sanghal A, Pant K, Natu SM, Nischal A, Nath R. An Experimental Study to Evaluate the Preventive Effect of Zingiber officinale (ginger) on Hypertension and Hyperlipidemia And its Comparison with Allium sativum (Garlic) in Rats. Journal of Medicinal Plants Research. 2012;6(25):4231-8.

4. Tanabe M, Chen YD, Saito K, Kano Y. Cholesterol Biosynthesis Inhibitory Component from $Z$. officinale. Chemical and Pharmaceutical Bulletin. 1993;41(4):710-3.

5. Uthumpa C, Ratana I, Rathapon A. Development of Nanoemulsion Formulations of Ginger Extract. Advanced Materials Research. 2013;684:12-5.

6. Frenoux JM, Prost ED, Belleville JL, Prost JL. Prost. A Polyunsaturated Fatty Acid Diet Lowers Blood Pressure and Improves Antioxidant Status in Spontaneously Hypertensive Rats. The Journal of Nutrition. 2001; 131(1): 39-45.

7. Putri AAB, Yuliet, Jamaluddin. Analysis of Albumin Levels of The Eels (Anguilla marmorata and Anguilla bicolor) and Examination of Its Open Wound Healing Activity on Rabbit (Oryctolagus Cuniculus). GALENIKA Journal of Pharmacy. 2016;2(2):90-5.

8. de Goede J, Geleijnse JM, Boer JM, Kromhout D, Verschuren WM. Marine (n-3) Fatty Acids, Fish Consumption, and The 10-Year Risk of Fatal and Nonfatal Coronary Heart Disease in a Large Population of Dutch Adults with Low Fish Intake. The Journal of Nutrition. 2010;140(5):1023-8.

9. Syahbana I, Suseno SH. The Oil Extraction from Eel (Anguila bicolor bicolor) Bone as by Product from Kabayaki Processing Industry. Pakistan Journal of Biotechnology.2014;11(1):25-31.

10. Savale S. 2015. A Review-Self Nanoemulsifying Drug Delivery System (SNEDDS). International Journal of Research in Pharmaceutical and Nano Sciences. 2015;4(6):385-97.

11. Maurya SD, Arya RKK, Rajpal G, Dhakar RC. SelfMicro Emulsifying Drug Delivery Systems (SMEDDS): A Review on Physico-Chemical and Biopharmaceutical Aspects. Journal of Drug Delivery and Therapeutics. 2017;7(3):55-65.

12. Gupta A, Eral HB, Hatton TA, Doyle PS. Nanoemulsions: Formation, Properties and Applications. Soft Matter. 2016;12:2826-41

13. Bhattacharjee, K. Importance of Surface Energy in Nanoemulsion. In Nanoemulsions-Properties, Fabrications and Applications; IntechOpen: London, UK, 2019; Available online: https://www.intechopen.com/onlinefirst/importance-of-surface-energy-in-nanoemulsion (accessed on 16 January 2020).

14. Sanghal A, Pant K, Natu SM. An Experimental Study to Evaluate the Preventive Effect of Zingiber officinale (ginger) on Hypertension and Hyperlipidemia and Its Comparison with Allium sativum (Garlic) in Rats. Journal of Medicinal Plant Research. 2012;6(25):4231-8.

15. Molfino A, Gioia G, Fanelli FR, Muscaritoli M. The Role for Dietary Omega- 3 Fatty Acids Supplementation on Older Adults. Nutrients. 2014;6(10):4058-73.
16. Leslie MA, Cohen DJ, Liddle DM, Robinson LE, Ma DWL. A review of the effect of omega-3 polyunsaturated fatty acids on blood triacylglycerol levels in normolipidemic and borderline hyperlipidemic individuals. Lipids in Health and Disease. 2015;14(53):1-18.

17. Widyasari RAHE, Kusharto CM, Budiwiryawan, Wiyono ES, Sugengherisuseno. Nutritive Value and Fatty Acids Profile of Fresh Indonesian Eel (Anguilla bicolor) and Kabayaki. Jurnal Sains Kesihatan Malaysia. 2014;12(1):41-6.

18. Sharifi N, Souri E, Ziai SA, Amin G, Amanlou M. Discovery of New Angiotensin Converting Enzyme (ACE) Inhibitor from Medical Plants to treat Hypertension using an in vitro assay. Daru. 2013;21(1):74.

19. Banerjee A, Qi J, Gogoi R, Wong J, Mitragotri S. Role of Nanoparticle Size, Shape and Surface Chemistry in Oral Drug Delivery. Journal of Controlled Release. 2016;238:176-185.Hea C, Hua Y, Yina L, Tanga C, Yina C. Effects of Particle Size and Surface Charge on Cellular Uptake and Biodistribution of Polymeric Nanoparticles. Biomaterials. 2010;31(2):3657-66.

20. Kulkarni SA, Feng SS. Effects of Particle Size and Surface Modification on Cellular Uptake and Biodistribution of Polymeric Nanoparticles for Drug Delivery. Pharmaceutical Research. 2013;30(10):2512-22.

21. Honary, S, Zahir, F. Effect of Zeta Potential on the Properties of NanoDrug Delivery Systems -A Review (Part 2). Tropical Journal of Pharmaceutical Research. 2013;12(2):265-73.

22. Khoshnevisan K, Barkhi M. Information about Zeta Potential; 2015. \{[cited 2018 Des 20]. Available from: https://www.researchgate.net/publication/275834023.

23. Mahboobian MM, Foroutan SM, Aboofazeli R. Brinzolamide- Loaded Nanoemulsions: In vitro Release Evaluation. Iranian Journal of Pharmaceutical Sciences. 1993; 12(3): 75-93.

24. Patel MJ, Patel NM, Patel RB, Patel RP. Formulation and Evaluation of Self-Microemulsifying Drug Delivery System of Lovastatin. Asian Journal of Pharmaceutical Sciences. 2010;5:266-7.

25. Smith DG. Epidemiology of dyslipidemia and economic burden on the healthcare system. American Journal of Managed Care. 2007;13(10):568-71.

26. Akinyemi AJ, Ademiluyi AO, Oboh G. Inhibition of Angiotensin-1-Converting Enzyme Activity by Two Varieties of Ginger (Zingiber officinale) in Rats Fed a High Cholesterol Diet. Journal of Medicinal Food. 2014;17(3):317-23.

27. Ong SLH, Zhang Y, Whitworth JA. Mechanisms of Dexamethasone-Induced Hypertension. Current Hypertension Review. 2009;5(1):61-74.

28. Sharon L.H. Ong, Yi Zhang and Judith A. Whitworth. 2014. Mechanisms of Dexamethasone-Induced Hypertension. Current Hypertension Reviews 5:61-74.

29. Safaeian L, Sajjadi SE, Javanmard SH, Gholamzade H. Antihypertensive and antioxidant effects of hydroalcoholic extract from the aerial parts of Kelussia odoratissima Mozaff. In dexamethasone-induced hypertensive rats. Advanced Biomedical Research. 2016;5(25):1-10. 